\title{
火山灰土壌の腐植特性の空間分布の推移にみる環境变化 一赤城火山南簏注おける事例—
}

\author{
渡 辺 真 紀 子*

\begin{abstract}
A Study of the Environmental Changes Inferred from the Spatial
Distribution of Soil Humus Characteristics in the Southern

Foot Area of Akagi Volcano, Central Japan
\end{abstract}

Makiko WATANABE

\begin{abstract}
:
By a series of studies to clarify the humus characteristics of volcanic ash soils and soil forming environment, the influence of climate variation was recognized in the eastern foot area of Nantai Volcano, Nikko (Watanabe 1985, 1987). The purpose of this study is to obtain useful information for the reconstruction of global scaled environmental changes from spatial distribution of soil humus characteristics. Volcanic ash soils developed in the southern foot area of Akagi Volcano were examined as a case.
\end{abstract}

The result is summarized as follows.

1. Soils developed over southern foot area of Akagi Volcano show several types of soil profiles regulated by the thickness and rate of tephra deposits and geomorphic surfaces. On mountain slopes formed by pyroclastic flow, brownish volcanic ash bed are to be seen between surface and buried humus layer. Soils distributed on central cone lacustrine surface have thick and dark humus layer called "gleyed Kuroboku". Soils with light humus layer develop on piedmont surface under the influence of artificial activity. The brownish volcanic ash bed mentioned above is difficult to distinguish from this layer.

2. The chronological sequence of soil formation in the study area was considered on the basis of properties of soil parent materials and radiocarbon dates. Horizon $I$ is the layer which continues to accept humus supply and humification under soil forming environment in the present. Fresh volcanic ash errupted from Asama and Haruna Volcano, about 200-1700 years ago are included in this layer. Horizon II correspondent to the brownish volcanic ash bed has accepted humus substances from the upper layer. Though the source volcano is unknown, this layer is assumed to be deposited about 4,000 years ago. Horizon III, a buried humus layer intercepted from surface environment, started soil formation about 9,000 years ago following to the erruption of Asama Itahana Yellowish Pumice (YP).

3. The vertical distribution of humus characteristics (brightness of soil color, carbon content and humus composition) was classified into two types, which reflects the conditions of vegetation and groundwater level regulated by gemorphic surface.

4. The spatial distribution patterns of humus characteristics such as carbon content and

*お茶の水女子大学地理学教室 Department of Geography, Ochanomizu University 
$\mathrm{RF}$ value of humic acid in each horizon show vertical zonality. The principal areas of humus accumulation in the age of horizon II and III formation were located in higher location than present, about $400 \mathrm{~m}$ upward. Humic acid classified such as type $\mathrm{A}+, \mathrm{P}++$, have remarkable absorption spectra near $615,570,455 \mathrm{~nm}$ which are regarded to be the features of soils formed under vegetations such as Fagus, Quercus mongolica and also under cool and wet condition in the study area. The appearance of these humic acid types in each horizon also tend to move its location upward by $300 \mathrm{~m}$ in the age of horizon III formation.

\section{I. はじめに}

古環境指標としての土畩は, 地形面の新旧によって時間尺度を与えられた, レリック土畩 (relic soil) の分布や, 土㙵断面における暗色帯の出現などを手がかりに，これまでに古環境の推定に貢献してきた (松井・加藤 1962 ; 黒部 1963 ; 浅海 1967など)。しかし, 土畩の物理化学的性質による土䁃生成と環 境変化に関する定量的な研究は, 土壤生成作用が複雑であるがにまだ十分な成果が得られていない。 ところで, 火山灰土㙥は, 火山活動の盛衰と植物からの有機物の供給によって時間の尺度を与えられ, 地表環境全般にわたる多様な情報を空間的, 時間的連続性をもって提供するといえる。そして, 腐植 (humus $)^{1)}$ は, 土袞の物理化学的性質のうち, 土壇体の最表層にあって, 最も敏感に環境条件を反映するだけ でなく, 土壤生成過程に積極的に関与する重要な構成物（加藤 1971）である。

足立 (1973) をはじめとして, 内外の火山灰土赫分布域における事例研究から, 火山灰土畩の腐植生成 と水熱条件との間に滵接な関係が認められている。そして, 火山灰土壌の腐植特性が環境の指標になり うることが示唆されている。しかし，腐植は土壌で無機化するために保存されにくく，その特性は比較的 短期間に生成環境の変化に対応した平衡状態に達するので, 古気候の復元に適さないと判断される（BIRKELAND 1974)。従来のような視点から，すなわち土鎄断面内における腐植特性の絶対值の変化量と環境 変化，とくに気候変化あるいはこれを媒介する植生変化を結びっけて議論することは不適当であり，多く の成果は望めない。

本研究は, 火山灰土壌の腐植特性の空間分布を明らかにすることによって, 自然環境の広域的な変遷と 土壤生成過程の関倸を解明し，古環境復元手段としての有用性を検討することを目的とする。ここで用い る空間分布とは，平面空閒をさす。第 1 図に示すように，土㙥断面を点 $\left(\mathrm{x}_{\mathrm{i}}, \mathrm{y}_{\mathrm{j}}\right)$ とする点事象の集合に よって, 平面分布が形成される。空間分布は, 時間的連続性をもつ複数の平面分布 $\left(h_{1}, h_{2}, h_{3}, \cdots\right)$ か ら構成されるものである。

本稿では, 北関東赤城火山南麓に発達する火 山灰土畩の採取試料について行った土㙥腐植特 性の室内分析結果をとに, 火山灰土潩腐植特 性の空間的分布から得られる古環境情報の意義 について考察する。

\section{II. 調查地域と研究方法}

赤城火山南麓斜面（第 2 図）には, 緩傾斜を なす火砕流堆積面上に降下堆積した火山灰を母 材とする, 黒ボク土が発達している。本地域は 榛名二ッ岳軽石 $\mathrm{FP}$ 分布域の 南限より 南に位 置しているため，北東麓斜面に広く分布するよ うな火山放出物未熟土は見られない。

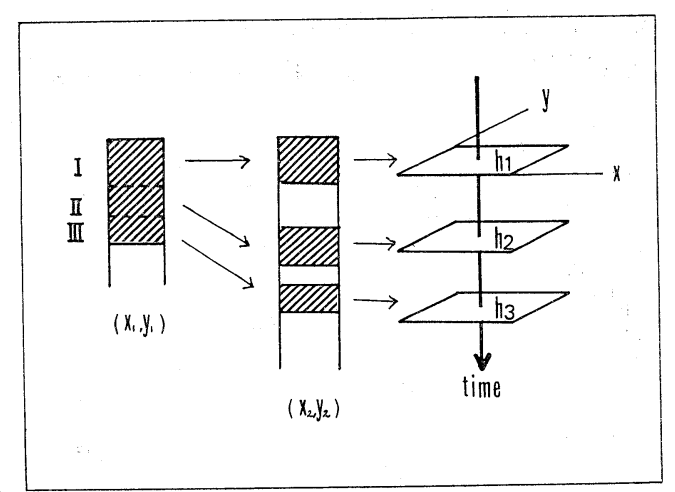

第 1 図 腐植特性の空間分布概念図

Fig. 1 Concept of spatial distribution of soil humus characteristics 


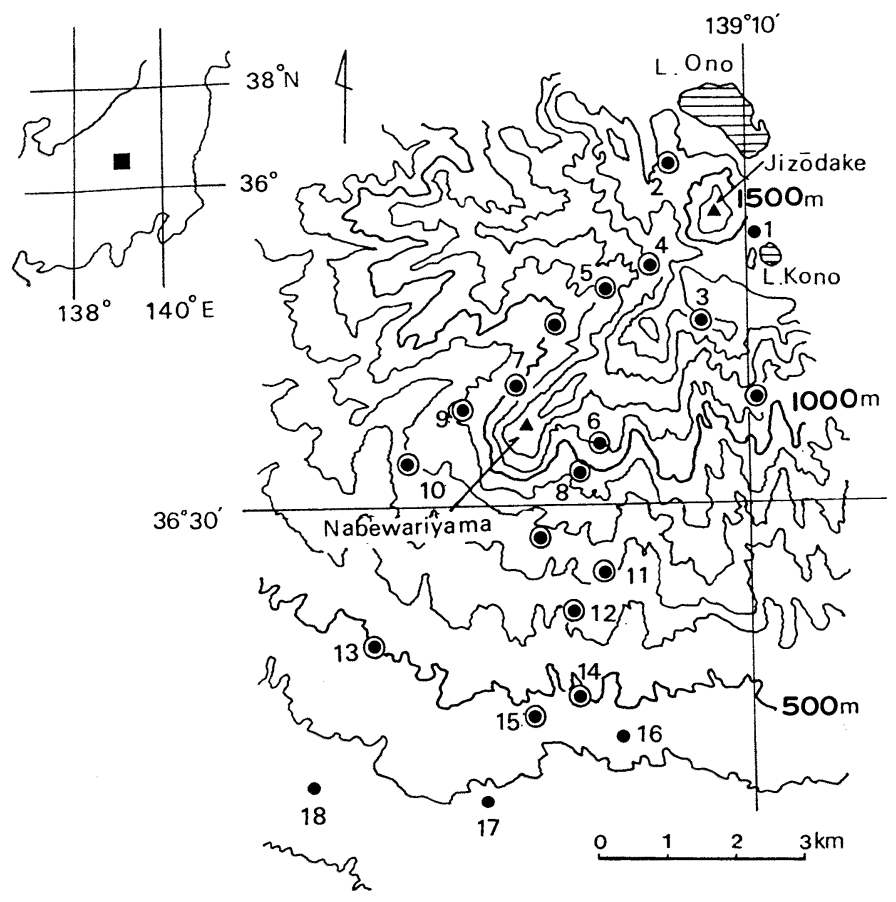

第 2 図調査地域とサンプリング地点，図中の番号は第 2 表のもの と対応する.

Fig. 2 Study area and the sampling sites. The numbers correspond to those on table 2
第 3-a 図 は赤城山南麓鍋 割山西土壤 $(1020 \mathrm{~m})$ の断面形 態である。図に示すような表 土腐植層と埋没腐植層をもつ 土袞断面が，標高500-1400m の範囲で分布している。調査 地域における腐植層の発達形 態を模式化したのが，第 4 図 である。表土腐植層の母材 は，新井（1972）によれば， 浅間降下テフラ $\mathrm{A}, \mathrm{B}, \mathrm{C}$ お よび FA（FP と同起源の火 山灰）と考えられる。表土腐 植層直下のローム層（土層 4）には白色軽石が，また埋 没腐植層には下位口-ム層 （土層 7, 板鼻黄色軽石層 YP）と同じ乳白色ないし橙 色の軽石の混在がそれぞれ認 められる。2つの腐植層には さまれる暗赤褐色口ーム層 は，傾斜が緩やかになる標高 500 から $800 \mathrm{~m}$ 付近で厚くな ることから，崩積物の混入は

否定できないが，土㙥断面の特徴から，主として風成堆積物であると考えられる。標高 $500 \mathrm{~m}$ 以下の斜面 には淡色黒ボク土が分布し，埋没腐植層は確認できない。また山頂平坦面は，後期中央火口丘湖成層堆積 面（形成時期は鹿沼降下軽石 KP の噴出後，およそ30,000年前）に相当し（守屋 1968）そそこには多湿 黒ボク土が見られる。なお，斜面中腹の寄生火山である鍋割山は急峻な斜面をなし，安山岩質の岩屑土が 生成され，黒ボク土は発達しない。

研究方法は第 5 図に示すとおりである。試料は原則として，土㙵層位学的区分にもとづいて各層位から

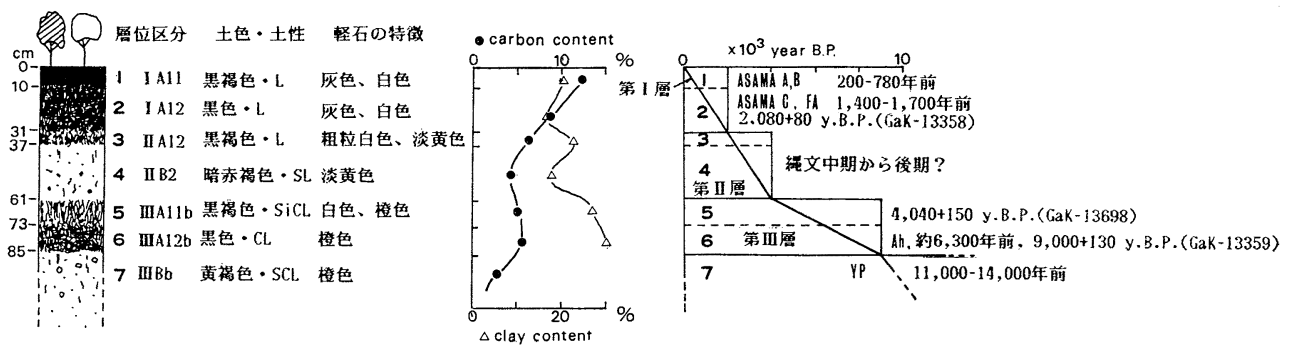

a)

b)

第 3 図 a) 柱状図（鍋割山西，1020m）と b）腐植層の生成過程

Fig. 3 a) Diagrammatic profile and b) scheme of soil formation of Nabewariyama soil (1020 m) 


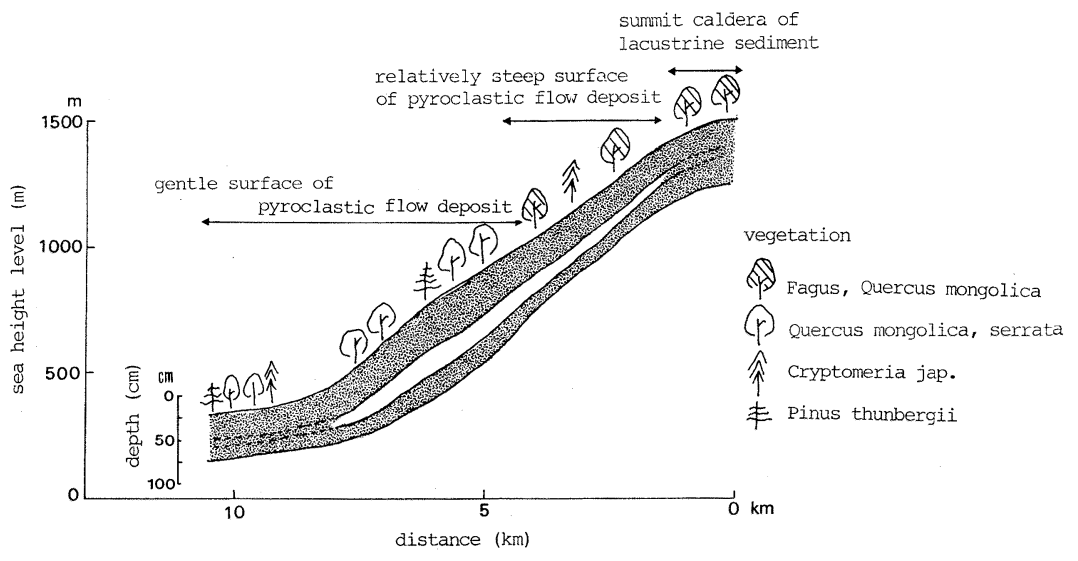

第 4 図 赤城火山南麓斜面における腐植層の発達形態（模式図），距離：地蔵岳山 頂からの距離 $(\mathrm{km})$

Fig. 4 Topographical sequence of Akagi soil. distance: distance from Jizodake $(\mathrm{km})$

およそ $15-20 \mathrm{~cm}$ おきに採取した。土壤腐植特 性の量・質的変化を明らかにする指標として, 腐植集積度, 土㙵暗色度, 腐植化度の 3 つの要 素を選定し，それぞれ，全炭素含有量の定量， 土壤明度測定, 腐植形態分析によって特性值を 求めた。また代表地点について粒径組成, 一次 鉱物組成，火山ガラス形態を調べ，これをもと に地質学的層序の対比を行った。分析方法は以 下のとおりである。

i）腐植集積度

全炭素含有率 : 硫酸希勫熱法

全窒素含有率：CN コーダー(柳本MT-500) を使用した。

ii）土㙵暗色度

肉眼では判定がむずかしい黒土層の土色につ いて, 客観性と高い精度を得るために, 色差計 （東京電色 TC 3600）を用いて, I. C. I 表色

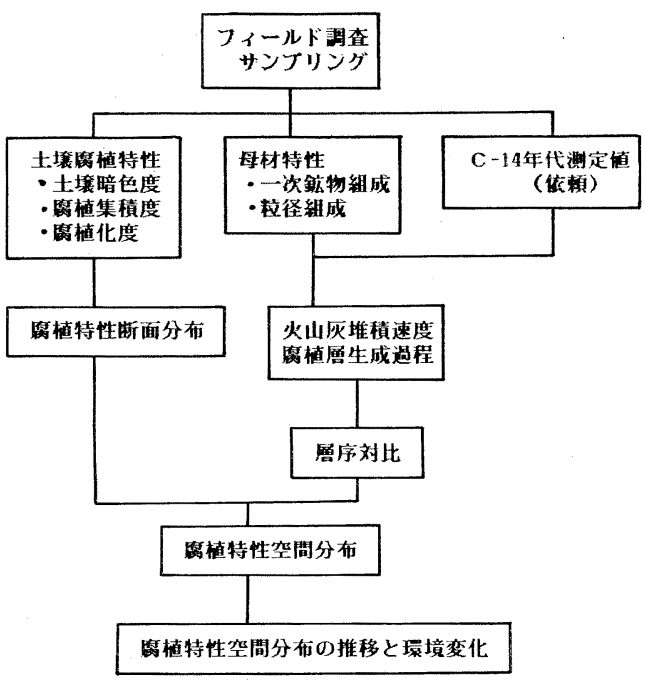

第 5 図 研究方法を示すフローチャート

Fig. 5 Flow chart of the study method

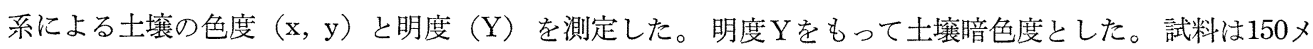
ッシュ $(0.105 \mathrm{~mm}$ 以下) にふるった乾土を使用した。

iii）腐植化度

腐植形態分析 : 熊田・太田法 ( $\mathrm{NaOH}$ 抽出部のみ)。水酸化ナトリウム抽出部の腐植酸挍よびフルボ酸 の量(乾土 $1 \mathrm{~g}$ 当たりの $0.1 \mathrm{~N}-\mathrm{KMnO}_{4}$ 消費量 $\mathrm{ml}$ ) をそれぞれ $\mathrm{a}, \mathrm{b}$ とするとき, 全腐植中の腐植酸 (沈 澱部割合) $\mathrm{PQ}=(\mathrm{a} /(\mathrm{a}+\mathrm{b})) \times 100(\%)$, 腐植酸の 相対色度 $\mathrm{RF}=\left(\right.$ 腐植酸比色液の $\mathrm{K}_{600} /$ 比色液 $30 \mathrm{ml}$ 当

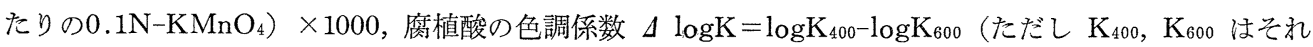


ぞれ $400 \mathrm{~nm}, 600 \mathrm{~nm}$ における吸光度) である。吸光度の測定には日立自記分光光度計 320 型を使用した。

iv）粒径組成

有機物分解処理を行った試料について国際法にもとづく粗砂，細砂，シルト，粘土の画分の重量\%を定 量した。粘土の分散は超音波処理 $(26 \mathrm{kHz}, 20 \mathrm{~min}$.) と分散剂 $(\mathrm{HCl}, \mathrm{pH} 4.0)$ によった。粘士とシルト の採取は沈降法に従った。

v）一次鉱物組成と火山ガラス形態

細砂試料 (0.1-0.2mm) について双眼顕微鏡と偏光顕微鏡下で粒子数\%を計測した。火山ガラスについ ては，0.02-0.1mm の画分の形態的特徴と相対量（4階級区分）を検鏡した。

さらに腐植層の生成年代を知る手がかりとして, 全腐植を試料とする ${ }^{14} \mathrm{C}$ 絶対年代測定值を求めた。ま

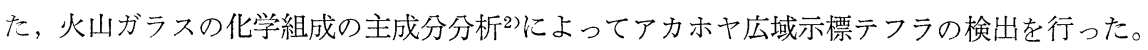

\section{III. 層序対比亡腐植層生成年代}

火山灰土壤の場合, 母材テフラの堆積による地層の層理と土壌生成作用による土層分化とが重複して断 面に現れる。したがって，土壤学的層位と地質学的層位とは一致しないことがある。ここでは，ローム層 の介在する土壌断面 (鍋割山西, $1020 \mathrm{~m}$ ) とロームの介在が明瞭でない土壌断面（金丸 $380 \mathrm{~m}$ )の母材特 性を第 1 表において比較し，両者の地質学的層位の対比を試みた。

粒度組成，一次鉱物組成と火山ガラスの特敷から，金丸土壤 6 層は鍋割山 7 層に対比される。この $2 つ$ の土層は一次鉱物組成の (opx/cpx) 比が小さく, 単斜輝石 (cpx) の割合が相対的に大きい。また, 火山 ガラスは軽石型のうち，とくに繊維状のものが多い。鍋割山 $5 ， 6$ と金丸 4,5 は粘土含有率が高く, 一 次鉱物組成は，磁鉄鉱の割合が多くなるという共通点をもつ。鍋割山 6 と金丸 5 には，バブル型平板状の ガラスが含まれる。このうち，鍋割山 6 の火山ガラスの化学組成の主成分比を調べたところ，アカホヤ火 山灰に同定される火山灰が検出された ${ }^{3)}$ 。一方，金丸 5 のガラスは検出率が低く，化学組成によるアカホ ヤの確認はできなかった。

鍋割山 4 は，輝石類を除く鉱物の割合が小さい，特異な層であり，金丸土壌での対比は明蹽でない。鍋 割山 4 層に相当する褐色ローム層は，おそらく金丸において堆積量が少なかったと考えられる。鍋割山 3 は opx/cpx 比が比較的大きく，角閃石が多いこと，さらに火山ガラスが少ないという点から，金丸 3 に 対比される。

鍋割山 $1 ， 2$ と金丸 $1 ， 2$ は，下位層のように，対比をする上での鉱物特性は，角閃石の含有率が比較 的高いほかは，顕著な類似点は見られない。これには，金丸土畩の表土攪乱が可能性として考えられる。

以上の結果をもとに, 本地域に括ける腐植層火山灰の層序と腐植層の生成過程を考察すると第 $3-\mathrm{b}$ 図の ようになる。図中には, 腐植層の生成年代推定の根拠となる, 銅割山土珡の ${ }^{14} \mathrm{C}$ 年代值を明記した。 1 層 と 2 層は類似した母材特性をもち, 浅間降下軽石 A， B ，C と榛名二ツ岳火山灰 FA を含を表土腐植層 （第I 層）を形成しており，生成開始はおよそ 2,000 年前に始まるものと考えられる。3 層は角閃石と磁鉄 鉱の割合が多く，4層より粘土化が進んでいる母材特性をもっていることから，4層のローム堆積末期に おける土壤生成作用の進行とともに，新たに火山灰が混入した層と考えられる。なお，4層の堆積時期は 不明であるが，ここでは土壌腐植特性および上下層の ${ }^{14} \mathrm{C}$ 年代值より，繩文中期から後期と仮定する（第 II 層)。5 層と 6 層は軽石の特徵と一次鉱物組成が類似し, 粘土化が進んでいることから火山灰の堆積速度 が緩やか時期（9,000土130年 B. P.）に生成が開始された埋没腐植層（第III層）と考えられる。 5 層より 6 層の方が暗色を呈していることから，第而層生成初期（およそ9,000年〜 6,000年前）は草本植生が 主で あったが，後期になると森林植生が優勢となり，表土の退色が生じたものと推定される。第而層の生成期 は, 南関東における富士黒土層 (町田 1964) や十和田カルデラの浮石層にはさまれた埋没腐植層（大池 1972）などにみる, 全国的な黒土生成期に対比される。7 層は褐色の軽石質ローム層で, 火山ガラスの特 
第 1 表 土壤母材特性（粒径組成，有色鉱物組成，火山ガラス形態）の比較

Table 1 Comparative table of properties of soil parent materials (grain size composition, primary mineral composition, features of volcanic glass shades)

\begin{tabular}{|c|c|c|c|c|c|c|c|c|c|c|c|}
\hline \multirow{2}{*}{ 地点 } & \multirow{2}{*}{ 土層 } & \multirow{2}{*}{\multicolumn{2}{|c|}{$\begin{array}{l}\text { 深さ } \\
\mathrm{cm}\end{array}$}} & \multirow{2}{*}{ 明度 } & \multirow{2}{*}{$\mathrm{C} \%$} & \multicolumn{2}{|c|}{ 粒 } & \multicolumn{3}{|c|}{ 成 } & \multirow{2}{*}{$\begin{array}{c}\% \\
\text { total }\end{array}$} \\
\hline & & & & & & 粗砂 & 細砂 & シルト & & \pm & \\
\hline \multirow{7}{*}{$\begin{array}{l}\text { 鍋割山 } \\
1020 \mathrm{~m}\end{array}$} & 1 & \multicolumn{2}{|c|}{$0-10$} & 4.3 & 13.30 & 17.67 & 35.42 & 25.58 & \multicolumn{2}{|c|}{21.33} & 100.00 \\
\hline & 2 & \multicolumn{2}{|c|}{$10-31$} & 5.1 & 8.63 & 25.66 & 37.35 & 19.16 & \multicolumn{2}{|c|}{17.82} & 99.99 \\
\hline & 3 & \multicolumn{2}{|c|}{$31-37$} & 6.9 & 6.37 & 19.64 & 26.47 & 31.09 & \multicolumn{2}{|c|}{22.80} & 100.00 \\
\hline & 4 & \multicolumn{2}{|c|}{$37-61$} & 11.9 & 4.31 & 24.85 & 20.11 & 37.03 & & .02 & 100.01 \\
\hline & 5 & $61^{-}$ & & 9.0 & 4.83 & 11.44 & 26.11 & 35.08 & & .36 & 99.99 \\
\hline & 6 & $73-8$ & & 8.7 & 5.24 & 11.13 & 24.53 & 34.12 & & .23 & 100.01 \\
\hline & 7 & $85-$ & & 18.0 & 2.56 & 17.56 & 24.92 & 31.19 & & 33 & 100.00 \\
\hline & 1 & $0^{-}$ & & 9.2 & 4.78 & 30.76 & 33.85 & 19.96 & & 43 & 100.00 \\
\hline & 2 & $12-$ & & 7.9 & 3.98 & 37.41 & 33.35 & 17.32 & & .92 & 100.00 \\
\hline 金丸町 & 3 & $23-$ & & 8.2 & 2.92 & 34.74 & 31.65 & 19.32 & & 29 & 100.00 \\
\hline $380 \mathrm{~m}$ & 4 & $34-$ & & 8.0 & 4.38 & 22.21 & 30.58 & 27.65 & & .56 & 100.00 \\
\hline & 5 & $50-$ & & 11.4 & 3.56 & 25.19 & 21.39 & 22.60 & & 82 & 100.00 \\
\hline & 6 & $66^{-}$ & & 14.3 & 1.69 & 19.28 & 21.48 & 34.69 & & .54 & 99.99 \\
\hline 十屏 & & & 有 色 & 鉱 物 & 組 成 & & & $\%$ & 火山 & 价ス & 態** \\
\hline 去目 & opx & $\operatorname{cpx}$ & ho & $\mathrm{mg}$ & ol & bi & $\mathrm{sc}$ & & B-w & P-s & P-f \\
\hline 鍋-1 & 55.29 & 18.82 & 5.88 & 6.47 & 2.94 & 0.00 & 9.28 & 99.99 & \pm & H & H \\
\hline 2 & 58.16 & 17.73 & 8.51 & 4.96 & 2.84 & 0.00 & 6.71 & 100.00 & \pm & H & H \\
\hline 3 & 49.51 & 13.59 & 11.65 & 16.02 & 3.40 & 1.46 & 4.37 & 100.00 & & + & + \\
\hline 4 & 60.61 & 21.21 & 1.82 & 9.70 & 3.03 & 0.61 & 3.03 & 100.01 & & + & + \\
\hline 5 & 47.77 & 17.20 & 3.50 & 28.98 & 1.91 & 0.00 & 0.64 & 100.00 & & + & + \\
\hline 6 & 48.25 & 15.38 & 2.10 & 26.57 & 3.50 & 0.70 & 3.50 & 100.00 & \pm & H & H \\
\hline 7 & 35.63 & 22.99 & 3.45 & 24.14 & 5.75 & 0.00 & 8.05 & 100.01 & \pm & H & H \\
\hline 金-1 & 40.44 & 18.67 & 11.56 & 19.56 & 3.11 & 0.00 & 6.67 & 100.01 & & $H$ & $H$ \\
\hline 2 & 49.02 & 19.61 & 12.16 & 11.76 & 1.57 & 0.00 & 5.88 & 100.00 & & & H \\
\hline 3 & 47.16 & 18.34 & 12.66 & 16.59 & 0.87 & 0.87 & 3.49 & 99.99 & & + & + \\
\hline 4 & 46.05 & 19.74 & 6.32 & 25.26 & 2.11 & 0.26 & 0.26 & 100.00 & & $H$ & + \\
\hline 5 & 47.93 & 19.83 & 2.75 & 25.62 & 2.48 & 0.28 & 1.10 & 99.99 & \pm & $H$ & H \\
\hline 6 & 48.09 & 24.20 & 4.78 & 19.11 & 1.91 & 0.00 & 1.91 & 100.00 & + & H & H \\
\hline
\end{tabular}

* B-w：バブル型平板状 P-s: 軽石型スポンジ状 P-f：軽石型繊維状 士 :微量 +: 少し H: 多い $H$ : ひじょうに多い

徵と鉱物組成から，浅間火山起源テフラ YP (11,000-14,000年前, 町田 1977) に相当すると考えられる。

\section{IV. 腐植特性の断面分布}

第 2 表は土袞腐植特性（土袞明度 $\mathrm{Y}$, 腐植集積度 $\mathrm{C} \%$, 腐植化度）の断面分布を 6 地点について挙げた ものである。鉱物レベルでの母材特性比較を行わなかった地点における層序詨比にあたっては, 断面形態, 
第 2 表 土袞腐植特性（土色，腐植集積度，腐植化度）の断面分布

Table 2 Vertical distribution of soil humus characteristics (soil color, humus accumulation, humification)

\begin{tabular}{|c|c|c|c|c|c|c|c|c|c|c|c|}
\hline \multirow{2}{*}{ 地 点 } & \multirow{2}{*}{$\begin{array}{l}\text { 層位 } \\
\text { 区分 }\end{array}$} & \multirow{2}{*}{ 土層 } & \multirow{2}{*}{$\begin{array}{l}\text { 深さ } \\
\mathrm{cm}\end{array}$} & \multicolumn{2}{|c|}{ 土 } & 色 & \multicolumn{2}{|c|}{ 腐植集積度 } & 腐 & 植 化 & \multirow{2}{*}{$\frac{\text { 度 }}{\Delta \log K}$} \\
\hline & & & & $\mathrm{x}$ & $\mathrm{y}$ & Y & $\mathrm{C} \%$ & $\mathrm{C} / \mathrm{N}$ & $\mathrm{PQ}$ & R F & \\
\hline \multirow{5}{*}{$\begin{array}{l}\text { No. } 1 \\
\text { 小 沼 } \\
(1500 \mathrm{~m})\end{array}$} & I & 1 & 20 & 0.35 & 0.35 & 6.5 & 10.24 & 15.7 & 53.49 & 108.96 & .5065 \\
\hline & & 2 & 35 & 0.35 & 0.35 & 7.4 & 9.79 & 21.3 & 81.27 & 32.62 & .5302 \\
\hline & II & 3 & 48 & 0.36 & 0.36 & 7.6 & 10.66 & 25.2 & 64.84 & 97.95 & .5350 \\
\hline & III & 4 & 60 & 0.35 & 0.35 & 8.0 & 10.74 & 30.4 & 67.06 & 126.03 & .5416 \\
\hline & & 5 & 80 & 0.36 & 0.36 & 31.7 & 3.26 & 21.2 & - & - & - \\
\hline \multirow{7}{*}{$\begin{array}{l}\text { No. } 3 \\
\text { 小沼先 } \\
(1400 \mathrm{~m})\end{array}$} & I & 1 & 5 & 0.35 & 0.36 & 7.1 & 13.35 & 12.9 & 58.33 & 68.41 & .5524 \\
\hline & & 2 & 15 & 0.36 & 0.36 & 8.5 & 10.39 & 13.7 & 52.91 & 104.75 & .5345 \\
\hline & & 3 & 27 & 0.37 & 0.36 & 13.4 & 9.63 & 14.6 & 46.94 & 80.97 & .5512 \\
\hline & II & 4 & 35 & 0.37 & 0.36 & 12.5 & 9.10 & 17.7 & 44.94 & 95.88 & .5169 \\
\hline & III & 5 & 50 & 0.36 & 0.36 & 11.6 & 10.36 & 19.2 & 77.82 & 24.24 & .5311 \\
\hline & & 6 & 60 & 0.36 & 0.36 & 16.1 & 7.77 & 19.5 & 78.76 & 21.29 & .5453 \\
\hline & & 7 & 75 & 0.37 & 0.36 & 20.6 & 3.72 & 18.2 & - & - & - \\
\hline \multirow{7}{*}{$\begin{array}{l}\text { No. } 7 \\
\text { 鍋割山西 } \\
(1020 \mathrm{~m})\end{array}$} & I & 1 & 5 & 0.35 & 0.35 & 4.4 & 13.30 & 12.4 & 64.71 & 63.56 & .5811 \\
\hline & & 2 & 20 & 0.35 & 0.35 & 7.1 & 8.63 & 12.1 & 62.87 & 74.25 & .5628 \\
\hline & & 3 & 34 & 0.37 & 0.37 & 13.9 & 6.37 & 11.4 & 57.00 & 82.04 & .5500 \\
\hline & II & 4 & 50 & 0.38 & 0.37 & 14.1 & 4.31 & 11.1 & 26.23 & 81.92 & .5431 \\
\hline & & 5 & 67 & 0.37 & 0.37 & 11.5 & 4.83 & 12.2 & 53.87 & 65.91 & .5603 \\
\hline & III & 6 & 79 & 0.37 & 0.36 & 10.8 & 5.24 & 15.4 & 58.79 & 74.32 & .5657 \\
\hline & & 7 & 90 & 0.38 & 0.37 & 20.3 & 2.56 & - & - & - & - \\
\hline \multirow{8}{*}{$\begin{array}{l}\text { No. } 10 \\
\text { ゴルフ } \\
\text { 場 先 } \\
(800 \mathrm{~m})\end{array}$} & I & 1 & 24 & 0.35 & 0.35 & 7.3 & 6.81 & 11.0 & 54.19 & 85.44 & .5742 \\
\hline & & 2 & 34 & 0.35 & 0.35 & 8.8 & 7.66 & 12.3 & 49.80 & 92.08 & .5587 \\
\hline & & 3 & 41 & 0.35 & 0.35 & 9.3 & 5.03 & 12.5 & 46.43 & 98.47 & .5515 \\
\hline & II & 4 & 47 & 0.38 & 0.37 & 13.9 & 3.51 & 13.5 & 31.64 & 99.69 & .5437 \\
\hline & & 5 & 62 & 0.39 & 0.37 & 12.1 & 3.00 & 12.2 & 27.38 & 78.20 & .5560 \\
\hline & III & 6 & 90 & 0.39 & 0.37 & 10.3 & 3.37 & 12.8 & 45.74 & 90.51 & .5734 \\
\hline & & 7 & 120 & 0.37 & 0.36 & 13.9 & 3.29 & 12.0 & 46.55 & 74.38 & .5850 \\
\hline & & 8 & 135 & 0.37 & 0.36 & 26.8 & 1.18 & 15.5 & - & - & - \\
\hline \multirow{8}{*}{$\begin{array}{l}\text { No. } 14 \\
\text { 落 合 } \\
(490 \mathrm{~m})\end{array}$} & I & 1 & 10 & 0.35 & 0.35 & 6.5 & 7.93 & 11.0 & 55.77 & 98.14 & .5534 \\
\hline & & 2 & 25 & 0.35 & 0.35 & 7.0 & 6.50 & 11.8 & 59.72 & 112.86 & .5335 \\
\hline & & 3 & 40 & 0.35 & 0.35 & 7.4 & 5.61 & 13.5 & 58.02 & 128.69 & .5298 \\
\hline & II & 4 & 55 & 0.37 & 0.36 & 10.2 & 3.36 & 18.2 & 49.58 & 105.78 & .5699 \\
\hline & & 5 & 75 & 0.36 & 0.36 & 9.1 & 4.58 & 23.2 & 64.44 & 112.24 & .5594 \\
\hline & III & 6 & 90 & 0.36 & 0.36 & 9.1 & 4.47 & 23.1 & 64.51 & 124.90 & .5636 \\
\hline & & 7 & 105 & 0.37 & 0.36 & 11.4 & 3.42 & 32.6 & 59.98 & 114.99 & .5825 \\
\hline & & 8 & 120 & 0.38 & 0.37 & 18.4 & 1.44 & 49.5 & - & - & - \\
\hline \multirow{6}{*}{$\begin{array}{l}\text { No. } 17 \\
\text { 金 丸 } \\
(380 \mathrm{~m})\end{array}$} & I & 1 & 10 & 0.36 & 0.36 & 11.1 & 4.78 & 14.6 & 49.67 & 80.64 & .5491 \\
\hline & & 2 & 20 & 0.36 & 0.36 & 9.2 & 3.98 & 12.9 & 41.77 & 77.42 & .5369 \\
\hline & II & 3 & 30 & 0.36 & 0.36 & 9.5 & 2.92 & 13.2 & 45.17 & 89.95 & .5357 \\
\hline & & 4 & 40 & 0.36 & 0.36 & 9.3 & 4.38 & 16.3 & 46.75 & 109.69 & .5283 \\
\hline & III & 5 & 58 & 0.37 & 0.37 & 13.0 & 3.56 & 14.7 & 52.40 & 95.90 & .5437 \\
\hline & & 6 & 75 & 0.39 & 0.38 & 18.2 & 1.69 & 13.2 & - & - & - \\
\hline
\end{tabular}


軽石の特徴のほか色差計による土色を判定 基準として層位を区分した。たとえば，表 土腐植層（第 $\mathrm{I}$ 層）では色度 $\mathrm{x}, \mathrm{y}$ が等し く, 明度Yが小さいが，ローム相当層（第 II 層) では色度が変化し $(\mathrm{x}>\mathrm{y})$, 明度 $\mathrm{Y}$ が大きくなり，第I層よりもスペクトル色 の主宰波長が大きく, 赤味を増している。 埋没腐植層（第而層）では再び色度 $\mathrm{x}, \mathrm{y}$ が等しく, 明度Yが小さくなる。ところで 腐植層断面が一様に黒色化している地点 （小沼，金丸）では，第II層においても色度 $\mathrm{x}=\mathrm{y}$ となり，土色による層位区分の判別 はむしろ明度Yの方が有効である。

断面内の腐植特性変化を模式的にまとめ ると，第 6 図のように 2 つに類型化するこ とができる。まず，ローム層の介在が明瞭 な地点 (小沼先, 鍋割山西ほか) では, 第 I 層で明度が小さく, 黒色化が進み, 炭素 および窒素の含有率が高いので, 表土から の腐植の供給を盛んに受けながら微生物に よる腐植の分解活動も進んでいると考えら

\begin{tabular}{|c|c|c|c|c|c|}
\hline \multirow{2}{*}{ 地点 } & 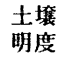 & 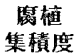 & \multicolumn{3}{|c|}{ 愿植化度 } \\
\hline & Y & $\mathrm{C} \%$ & $P Q$ & $\mathrm{RF}$ & $\Delta \log \mathrm{K}$ \\
\hline 小沼 & & & & & \\
\hline $\begin{array}{l}\text { 小沼先 } \\
\text { 鍋割山西 } \\
\text { 士ルフ場先 } \\
\text { 落合 } \\
\text { 金丸 }\end{array}$ & & & $y$ & & \\
\hline
\end{tabular}

第 6 図 腐植特性の断面分布の類型化，腐植諸特 性 $(\mathrm{Y}$ : 土䁃明度, $\mathrm{C}$ : 炭素含有率, $\mathrm{PQ}$ : 腐植 酸割合, $\mathrm{RF}$ : 腐植酸相対色度, $\Delta \log \mathrm{K}$ : 應 植酸色調係数).

Fig. 6 Abbreviated types classified according to the vertical change in humus characteristics ( $\mathrm{Y}$ : soil value, $\mathrm{C}$ : carbon content, $\mathrm{PQ}$ : ratio of humic acid to humus, $\mathrm{RF}$ : the depth of color of organic matter per unit mass, $4 \log \mathrm{K}$ : $\log \mathrm{K}_{400}-\log \mathrm{K}_{600}$, $\left(\mathrm{K}_{400}\right.$, $\mathrm{K}_{600}$ : optical density of humic acid at $400 \mathrm{~nm}$ and $600 \mathrm{~nm}$, respectively) れる。またこの層では, PQ は高く, 腐植 酸の生成がさかんであるが, RF 值が低く，かつ $\Delta \log \mathrm{K}$ が大きいことから，集積した腐植は若いた めに腐植化度は下位層に比べて低いことがわかる。ローム相当層である第II層では，土壤明度が高く，炭 素含有率, 窒素含有率, 腐植酸割合 $\mathrm{PQ}$ が低く, 腐植および腐植酸の量は少ない。PQ 值が低いのは, 低分子化合物であるフルボ酸の上からの浸潤のために相対的に腐植酸の割合が 減少していると考えられ る。な第 II 層で生成された腐植酸は相対色度 RF が大きく，色調倸数 $\Delta \log \mathrm{K}$ が小さいことから，表 土腐植層より腐植化が進んでいると判断される。かっての表土を形成していた埋没腐植層相当層の第皿層 では，土㙵明度が再び小さくなり，腐植および腐植酸の集積割合が増大するが，腐植化度は第 II 層よりも やや低下している。ところで, 本研究において行ったアルカリ $(\mathrm{NaOH})$ 抽出の腐植酸はおよそ 5,000 年 で腐植化度の最大值を示す（YosHIDA et al. 1978）ことから，第正層形成期の腐植については無機化が 進行しているものと考えられる。

一方，小沼土壇（標高 $1500 \mathrm{~m}$ ） は第 II 層，第而層における炭素含有率および炭素率が大きく，第 II 層 と第且層形成期における湿性条件が腐植の分解を抑制し，集積を促しているむのと考えられる。腐植化度 も第 II 層で低く，第而層で高くなり，地形因子に由来する土䱋生成条件の違いによって，他地点とは異な る断面変化をもつ。また，低標高に位置し，一様に暗色化している金丸土壌（380m）は，前述のように人 為的な表土挸乱の影響を受けていると考えられるが，腐植特性の断面変化は中腹斜面の土壌（鎘割山西ほ か）と同じ類型に分類できる。

以上の結果から, 現在の環境下で土壌生成作用を受ける表土腐植層（第 $\mathrm{I}$ 層）と, 断面上方からの腐植 物質の浸潤が加わることが予想される下層ローム層ないし相当層（第 II 層）と，現在の地表環境から 遮断 されている埋没腐植層（第而層）という，生成過程の違う 3 つの層位における腐植特性が明らかになった。 


\section{V. 腐植特性の空間分布}

腐植特性のらち腐植集積度と腐植化度の 2 要素について, それぞれの特性值の空間分布を求めた。特性 値は各層における最大值 P max で割り，無次元化してある。したがって，特性值1.0が各層における極大 頲を表す。

まず，腐植集積度（炭素含有率）特性值の空閒分布は第 7 図のとおりで, 第 $\mathrm{I}$ 層（表土腐植層）では標 高1000-1400m に集積の極大域の中心が現れる。第II層（ローム層ないし相当層）では，小沼 $(1500 \mathrm{~m}$ ）を 極大域として，鍋割山南東の $1100 \mathrm{~m}$ 付近まで集積域が伸びている。第而層（埋没腐植層ないし相当層）で 法小沼 $(1500 \mathrm{~m})$ と小沼先 $(1400 \mathrm{~m})$ を極大域として，標高が下がるにしたがって特性值が小さくなり， 腐植の集積度が減少する。腐植集積域と現在の植生分布とを対応させてみると，第 I 層における集積域は

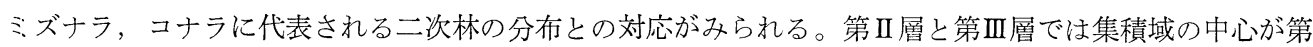
1 層よりも北上しており，現在の植生分布との対応はみられない。集積域の移動要因については，土壤中 の)植物珪酸体の抽出，鑑定などによって腐植の給源植生の変遷を明らかにした上での検討を要する。なお， 第 I 層と第而層の腐植集積域の下限高度は，およそ400m の差がみられる。

第 8 図では腐植化度指標のうち，腐植酸相対色度（RF 值）と熊田・太田（1963）の分類に準じた Na$\mathrm{OH}$ 抽出による腐植酸の類型について同様に空間分布を求めた。まず，RF 值は第 $\mathrm{I}$ 層ではさきの腐植集 積域で小さく，腐植化度が低くなっており，山頂と低標高に向けて特性值は大きくなり，腐植化が進んで いる。第I層と第而層においても腐植集積域の移動と対応して RF 值の極小域の中心が少し北に移り， また標高が低くなるにしたがって RF 值は大きくなり，腐植化が進む傾向を示す。これは低標高地点ほど 温暖条件の卓越にともなって腐植物質の分解が進み，腐植酸の重縮合が進しだ高次の腐植物質が生成され ていることに起因すると考えられる。

本地域における腐植酸の型は第 9 図に示すように $\mathrm{P}$ 型, B 型, $\mathrm{A}$ 型の 3 種類に分類され，腐植化の進ん だ $\mathrm{A}$ 型は低標高地点と山頂平坦部付近でみられる。山頂付近における腐植層は地形面に由来する卓越した 湿性条件の下で草本植生からの腐植供給を受けることによって, 森林植生よりも腐植化度の高い腐植が生 成されたと考えられる。とくにその傾向は, 山頂付近 (小沼 $1500 \mathrm{~m}$ ) の第正層で顕著に認められる。
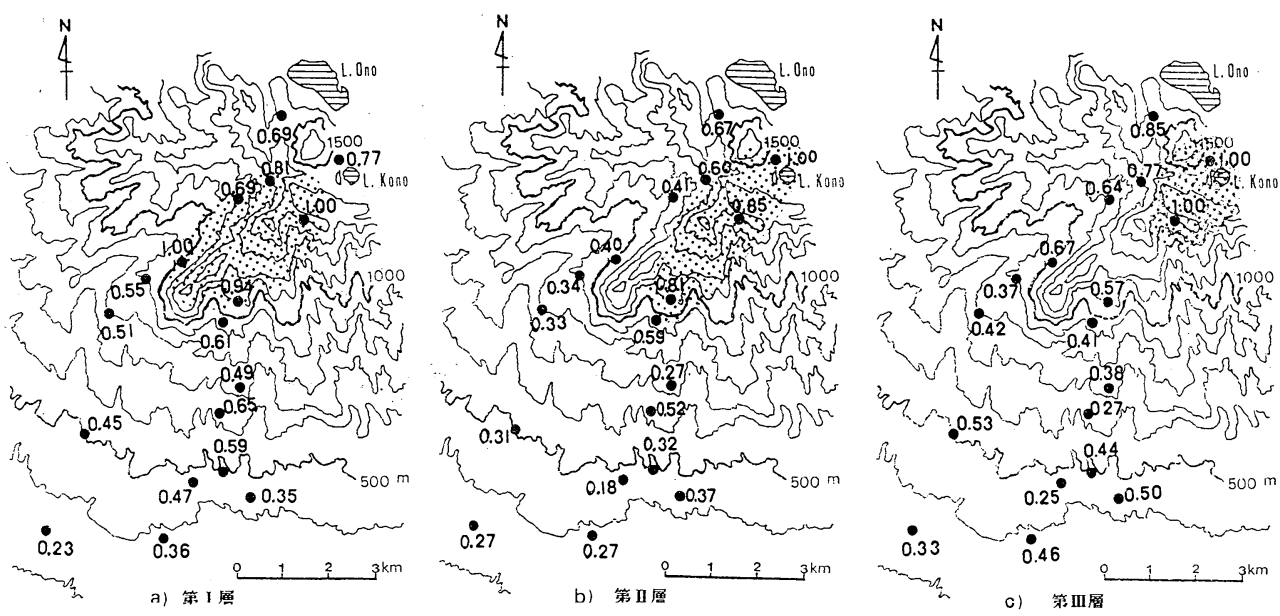

第 7 図 腐植集積度（炭素含有率； C\%特性值）の空間分布 $\mathrm{a}$ ）第 I 層 b) 第 II 層 c) 第 III 層

Fig. 7 Spatial distribution of humus accumulation (carbon content). a) horizon I, b) horizon II, c) horizon III 


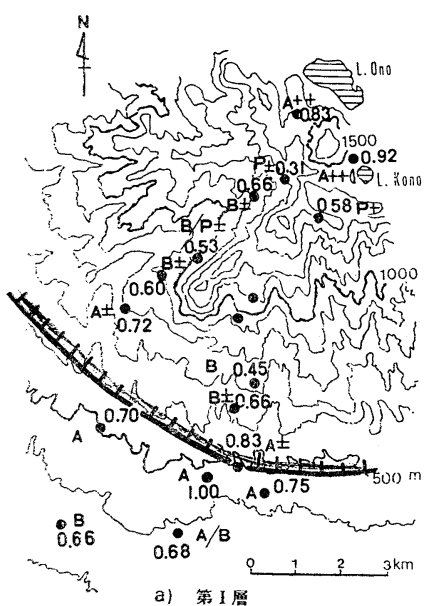

a) 第 I層

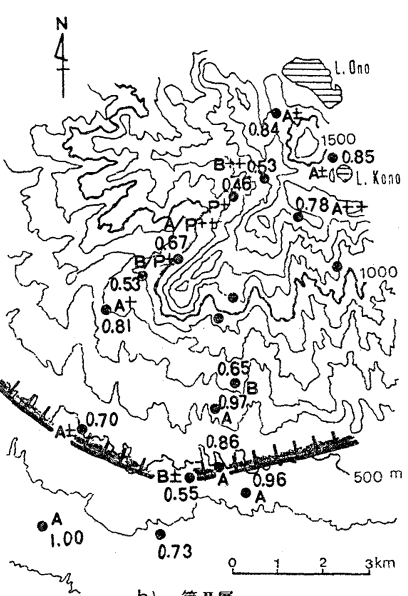

b) 第四層

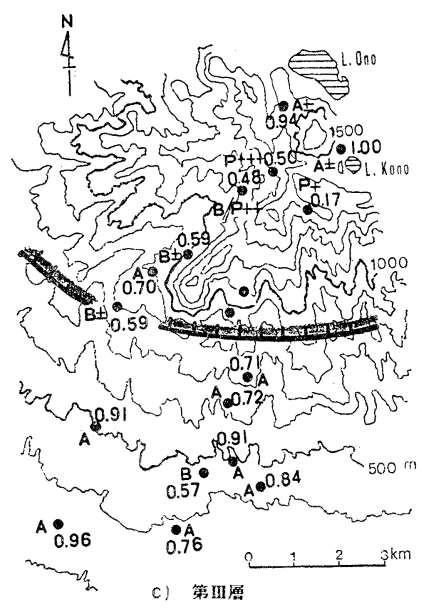

c) 第且層

第 8 図 腐植化度（相対色度 RF 特性值および腐植酸の型）の空間分布 a）第 I 層 b) 第 II 層 c) 第III層

Fig. 8 Spatial distribution of humification (RFvalue and types of humic acid). a) horizon I, b) horizon II, c) horizon III

ところで腐植酸の可視領域 $(\lambda ; 370-700$ $\mathrm{nm}$ ）に扔ける吸光曲線を比較すると，第10 図のように $615,570,455 \mathrm{~nm}$ 付近に吸收帯が 現れる場合がある。吸収帯出現の強弱によっ てさらに腐植酸の型に土,,,++++++ の符号をつけて細分類を行った。この吸收帯 の発生起源は Cenococcum graniforme と 推定されるかびの菌核の代謝産物（熊田 1981) としての緑色色素（ペリレンキノン系 色素) であることが知られ, 緑色腐植酸とも 呼ばれる。この色素に似た物質がこれまで に, 数種の木材腐朽菌から抽出されており (KUMADA 1967; SATO 1976), 植物 (と くに樹木）と共生関係にある系状菌の一種に よって生産される色素の残存形態であると考 えられる。腐植酸の吸収帯の出現強度が強い ほど, 相対的な緑色色素の含量率は増大する (SATO 1974)。

第 8 図に示す腐植酸の型の空間分布から, 腐植酸の緑色色素の分布下限は, 腐植層の生

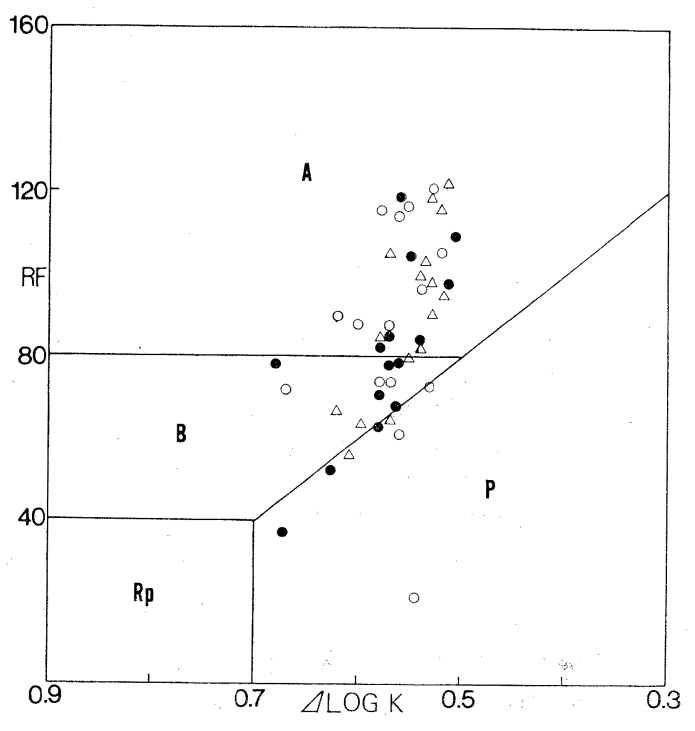

第 9 図腐植酸の分類, - : 第 I 層, $\triangle$ : 第 II 層, $\mathrm{O}:$ 第III層

Fig. 9 Classification diagram of humic acid. - : horizon I , $\Delta$ : horizon II, $\mathrm{O}$ : horizon III 成期によって推移する。すなわち, 第 I 層では山頂部(小沼 $1500 \mathrm{~m}$, 資料館 $1434 \mathrm{~m}$ )で緑色腐植酸の含 量が高く $(++)$, 標高 $500 \mathrm{~m}$ 付近まで, 腐植酸の緑色色素を確認できる。第II層では緑色腐植酸の含有量 が各地点ともに増加し, 分布の下限は, 堀久保 $(460 \mathrm{~m})$ まで拡張している。第而層では分布の下限が $800 \mathrm{~m}$ 付近に上昇し, 緑色色素の含有量も各地点で減少している。また, 第 II 層と第而層の緑色腐植酸の含有量 
694

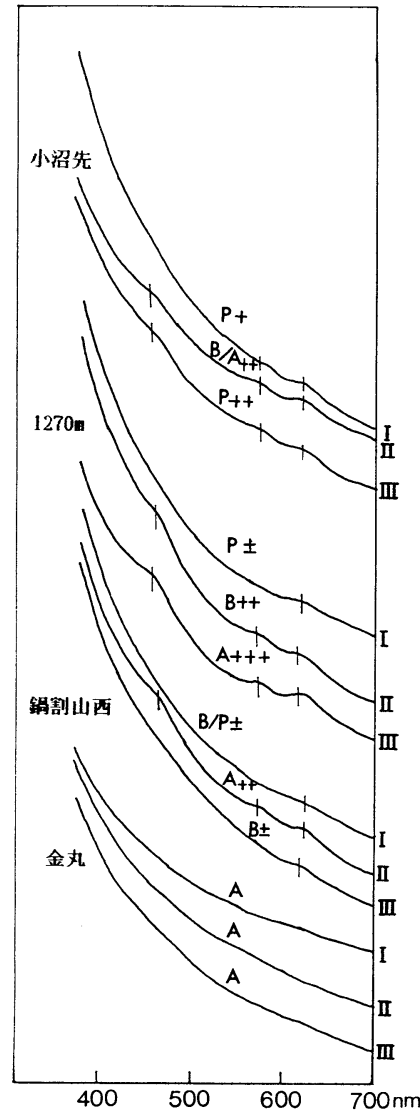

第10図 腐植酸の吸光曲線と腐 植酸の型の細分化

Fig. 10 Subdivisions of humic acid according to the shapes of absorption spectral curves.
渡 辺 真 紀子

は, 山頂部よりも, 標高 $1100 \mathrm{~m}$ から $1400 \mathrm{~m}$ の範囲で最も大きい。 本地域では, 表土腐植層における緑色腐植酸の分布の特徵か ら, 緑色腐植酸の生成には寒冷 (多湿) 条件と, 植生帯として, 落葉広葉樹林とくにブナ属 (Fagus) との関係が強く認められる。 これまでにも，KUMADA et al. (1967) や大角・太田 (1975) によって, 緑色腐植酸の生成の好適な水熱環境として, 寒冷多湿 条件が関与していることが指摘されている。

赤城火山周辺における潜在自然植生は, 宮脇 - 奥田 (1976) に よれば，海抜高度600-700m 付近に常緑広葉樹林 (シラカシ群集) と落葉広葉樹林（イヌブナ群集, クリーコナラ群集）の境界が求 められる。一方, 吉野 (1968) によれば, 前橋北部は, 冬季の強 い季節風のため常緑広葉樹の残存林が少なく, ウラジロガシなど の暖帯林の生育は，気候值から推定される分布限界よりも低標高 （およそ $500 \mathrm{~m}$ 付近）にあるとされる。このことから，本地域に おける緑色腐植酸の分布下限の移動と, 暖帯林の昇降との関係が 推察できる。ただし，暖帯林下の土壌においても緑色腐植酸の生 成が確認されている（河田 1975ほか）ので, 腐植酸の吸光特性 から植生帯を確定することはできない。なお，緑色腐植酸の分布 下限から推定される赤城火山南麓の植生帯の移動量は, 第 II 層は 第 I 層(現在)よりも $50 \mathrm{~m}$ 程度の下降，第III層は第 I 層より $300 \mathrm{~m}$ 程度の上昇となる。

\section{VI. まとめ}

以上の結果から赤城火山南麓を事例とする火山灰土壌の腐植特 性と生成環境について，つぎのようなことが明らかになった。

1. 赤城火山南麓には累積性火山灰土壌が分布し, 腐植層の断 面形態はテフラ堆積速度と地形面によって異なる。火砕流堆積面 に相当する山麓斜面では褐色ローム層を挾んで表土腐植層と埋没 腐植層が発達し, 中央火口丘湖成層堆積面に相当する山頂平坦部 では，一様に暗色を呈した多湿黒ボク土が発達する。また，低標 高の山麓緩斜面ではローム堆積層が薄く, 人為的作用（攪乱，削

剝）も加わって，ローム層の介在が不明瞭な淡色黒ボク土が発達する。

2. 土壌の母材特性と, 全腐植を試料とする ${ }^{14} \mathrm{C}$ 年代測定值をもとに, 本地域における層序の対比と腐 植層の生成年代を考察した。第 I 層は浅間と榛名火山を起源とする比較的新しい火山灰を母材とし, 現在 の環境下で腐植の供給を受ける表土腐植層である。第I層はおよそ3,000-4,000年前に降下堆積したと推 定される褐色ローム層ないしその相当層で, 上からの腐植物質の浸潤を受けていると考えられる。第而層 はアカホヤ火山灰を包含し, 浅間火山板鼻黄色軽石 (YP) の降下堆積後, 火山灰の堆積速度が緩やかな時 期（およそ9,000年前）に生成が開始され，比較的長い期間にわたり表土を形成していたと考えられる層位 で, 現在の地表環境から遮断されている埋没腐植層である。

3. 土壤暗色度, 腐植集積度と腐植化度の 3 要素について求めた腐植特性の断面分布は, 地形面に起因 する水分条件の違いとそれに規定される植生環境の違いによって，2つに類型化される。

4. 3つの層位（第 I 層, II 層, III層）ごとに腐植特性の空間的分布を求めると, 各層とも腐植集積度, 
腐植化度は標高の変化に対応する垂直成带性を示す。さらに，3つの層位の腐植特性の空間分布は，各層 の生成年代 (腐植供給開始時期) に伴って移動する。第皿層生成期において，腐植集積条件と緑色腐植酸 生成条件が現在よりも高度にして300-400m 程度の上昇していたと推定される結果を得た。

\section{VII. おわりに}

本研究によって, 腐植の集積度と腐植化度の空閒分布から腐植特性が垂直高度の変化と対応した変化を もつことが確認されたといえる。このような腐植特性の垂直成帯性は日光男体火山東麓に発達する火山灰 土壤でも認められ（渡辺 $1985 ， 1987$ ), 本地域においても腐植特性の空間分布が層位ごとに変化し, 腐植 層の生成過程において広域的な環境変化が生じたと推定しうる分析データを得た。従来のように単一の土 壤断面における腐植特性の変化をみるだけでなく，このように土壤腐植特性の垂直成带性の移動を調べる ことによって, 古環境の解明に有用な情報を得られるものと考えられる。

\section{謝辞}

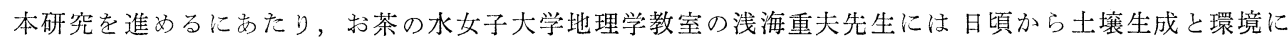
ついてご教示いただき，また東京農工大学土袞学教室の浜田龍之介先生ならびに坂上宽一先生には土㙵分 析のご指導をいただいた。東京都立大学地理学教室の町田洋先生にはアカホヤ火山灰標準試料の提供をい ただき，また有益なご助言を賜った。学習院大学年代測定室の木越邦彦先生には土墒試料の絶対年代測定 をお願いした。火山ガラスの主成分分析に関しては, お茶の水女子大学大学院生の徳井由美さんに測定を 枋覑いした。㧍茶の水女子大学地理学科の青木久美子さん, 稲永麻子さん, 木ノ下真紀さん, 森元子さ ん，吉住理恵子さんには土壌分析のご協力をいただいた。以上の方々に深く感謝いたします。

\section{注}

1）本研究では “腐植”を“土㙥有機物”と同義として扱う。

2）分析装置は，国立科学博物館所有の走查電子顕微鏡（JEOL, JSM-T200) 㧍よびエネルギー分 散型スペクトロメーター（LINK SYSTEMS）を使用した。

3）標準試料は，麇児島県国分市に㧍ける採取試料を使用した。

\section{文献}

浅海重夫（1967）：日本の土㙵分布に関する考察一地形面との対応. 㧍茶の水女子大学人文科学紀要, 20, 70-192.

新井房夫（1979）：関東地方北西部の繩文時代以降の示標テフラ層. 考古学ジャーナル，157，41-52. 大池昭二（1972）：十和田火山東簏に抢ける完新世カルデラの編年．第四紀研究，11，228-235.

大角泰夫・太田信婦（1975）：ネパール最西部地域の森林下の土壊の一般的性質について。ペドロジ スト, 19, 80-92.

大塚紘雄（1973）：鹿児島県垂水市大野原の火山性土鎄に関する研究（第 1 報）.土壤肥料学䧴誌，45, 197-203.

加藤芳朗（1971）：土壤．羽鳥謙三ほか編，第四紀，共立出版，167-203.

河田 弘 (1975)：褐色森林土の腐植の形態. 林試研報, 270, 89-110.

熊田恭一・太田信婦（1963）：腐植の抽出にっいて。土㙵肥料学雑誌，34，417-422.

- (1981): 土鎄有機物の化学（第 2 版）学会出版センター, 299p.

黑部 隆 (1963)：立川口ームの腐植に関する生成学的研究. 土壤肥料学雑誌，34，182-194.

守屋以智雄 (1968)：赤城火山の地形及び地質. 前橋営林局, 65p.

町田 洋 (1964)：Tephrochronology による富士火山とその周辺地域の発達史。地学雑誌，73，293308.

- (1977) : テフロクロノロジー，日本第四紀学会編，日本の第四紀研究，東京大学出版会，59-68.

松井 健・加藤芳朗 (1962)：日本の赤色土壤の生成時期・堆積環境にかんする二三の考察. 第四紀 研究, 2, 161-179.

宮脇 昭・奥田重俊（1976）：首都圈 の潜在自然植生．横浜国大環境科学研究紀要， 2, 95-114. 
吉野みどり（1968）：関東地方における常緑広葉樹林の分布. 地理学評論，41，674-694.

渡辺真紀子（1985）：男体火山東麓域における腐植質火山灰土壌の腐植特性一生成環境推定の試論一. 地理学評論, 58, 237-254.

渡辺真紀子（1987）：男体火山東麓域に扮ける土畩腐植特性の垂直分布と水平分布. 地理学評論, 60, 251-264.

Birkeland, P. W. (1974) : Pedology, Weathering and Geomorphological Research, Oxford Univ. Press, 285p.

KUMADA, K. (1967) : Green humic acid and its possible origin as a fungal metabolite. Nature, 214, 631-633.

SAto, O., Osumi, Y., and OHтA, S. (1967): Humus composition of mountain soils in Central Japan with special reference to the distribution of $\mathrm{P}$ type humic acid. Soil Sci. Plant Nutr. 13, 151-168.

SATO, O. (1974): Methods for estimating Pg content in $\mathrm{P}$ type humic acid and for calculating LlogK of its Pg fraction. Soil Sci. Plant Nutr, 20, 341-651.

(1976) : A green pigment similar to the Pg fraction of P type humic acids and related compounds produced by litter-decomposing fungi. Soil Sci. Plant Nutr. 22, 269-275.

Yoshida, M., Sakagami, K., Hamada, R., and Kurobe, T. (1978): Studies on the properties of organic matter in the buried humic horizon derived from volcanic ash, Soil Sci. Plant Nutr., 24, 277-287. 